Man and Nature

MAN AND NATURE

L'homme et la nature

L'HOMME ET LA NATURE

\title{
Enlightened Despotism and the Resistance to Arbitrary Taxation in Southwest Germany After the Seven Years' War
}

\section{Helen Liebel-Weckowicz}

Volume 5, 1986

URI : https://id.erudit.org/iderudit/1011855ar

DOI : https://doi.org/10.7202/1011855ar

Aller au sommaire du numéro

Éditeur(s)

Canadian Society for Eighteenth-Century Studies / Société canadienne d'étude du dix-huitième siècle

ISSN

0824-3298 (imprimé)

1927-8810 (numérique)

Découvrir la revue

Citer cet article

Liebel-Weckowicz, H. (1986). Enlightened Despotism and the Resistance to Arbitrary Taxation in Southwest Germany After the Seven Years' War. Man and Nature / L'homme et la nature, 5, 99-118. https://doi.org/10.7202/1011855ar

Copyright (c) Canadian Society for Eighteenth-Century Studies / Société canadienne d'étude du dix-huitième siècle, 1986
Ce document est protégé par la loi sur le droit d'auteur. L'utilisation des services d'Érudit (y compris la reproduction) est assujettie à sa politique d'utilisation que vous pouvez consulter en ligne.

https://apropos.erudit.org/fr/usagers/politique-dutilisation/ 


\section{Enlightened Despotism and the Resistance to Arbitrary Taxation in Southwest Germany After the Seven Years' War}

The history of rural and urban rebellions in the German states may be traced to the late middle ages. The medieval resistance to new taxes and labor services usually also involved an assertion of the right to keep freedoms already granted or acquired. ${ }^{1}$ The conception of what constitutes an uprising or rebellion has varied considerably in modern historiography. German historians use words like Aufstand for rising, or Unruhen for unrest, while Tumulte is reserved for demonstrations, riots, and small scale conflicts. The full scale revolts in the German towns between the fourteenth and sixteenth centuries were, as in Renaissance Italy, directed against the exclusive control of the town governments by the patricians. Sometimes as in Cologne in 1370, or in Brunswick in 1374-86, the artisans in the guilds succeeded in gaining access to office or turfing out the patrician councillors. The rural rebellions from the 1336-39 Armlederbewegung (Poor Leather Movement) to the great Peasant's War of 1525 show an alliance between the town's lower classes and the peasants. The object of attack was against those who controlled rural capital, which in the German Peasants' War of 1525 as well as the Wat Tyler Rebellion of 1381 in England, was in the hands of the wealthy clergy: the bishops, abbots, and great orders. ${ }^{2}$ 
In the rich history of rebellion found in southwestern Germany, the more modern political elements of the Poor Conrad rebellion of 1514 in Württemberg are especially interesting for the development of institutions of representative government. For the first time since 1215 and Magna Carta in England, political concessions resulted from a rebellion which were integrated into the permanent institutions of government. Both the Wat Tyler uprising and the many fourteenth-century town rebellions in Europe had failed in this regard. In Württemberg in 1514 it was the 5000 rebellious peasants and their allies among the townsmen who were able to negotiate with the reigning duke, the higher governmental authority, not the local one in this case, and to successfully conclude the Tübingen Compact of 1514. This became the basic constitution of Württemberg Duchy and was as staunchly defended in the 1764 tax revolt as in the sixteenth century. Although it did not free all Württembergers from serfdom, for most commoners were already free men and tenant farmers by the sixteenth century, it defined the basic rights of the commons to approve taxes and of the citizens to bear arms only in the defense of the land. It is the free man's right to enjoy free disposition over his property and his migrations which the charter entrenched. The estates or parliament had a history traceable to its first recorded meeting in 1457, and retained the power to approve tax appropriations up to the Napoleonic Wars. The net result of the Tübingen Compact was, that the dukes were legally committed to a system of negotiation with the parliament whenever there were financial difficulties to overcome. ${ }^{3}$

The rebelliousness in the towns of Württemberg during the 1760s had a less organized character than that of any of the late medieval occurences, although still similar in some of their institutional characteristics. They fall rather into the category of a boycott or a strike, especially in the case of the opposition to the 1764 property tax. Both citizens and town officials stood together in their opposition to the ducal administration and the duke himself. Unlike so many early modern uprisings such as the Peasants' War of 1525, which was widespread among the south German towns, and which involved the armed warfare of organized peasant bands under military leadership and an attack on town governments and their constituent institutions, the eighteenthcentury resistance looked to the duchy's parliament for leadership and was led by many of the representatives of the local governments. The 1764 resistance to the tax did not reach the same proportions as in the 1525 war, but had the active support of the parliament and the elected town officials against the ducal bureaucracy. The characteristic which gives the conflict a revolutionary connotation is the use of military force and the punishment of the opposition leaders by arrest, fines, and the use 
of strong-arm tactics to compel obedience to the arbitrary policies of the executive authority. ${ }^{4}$

The leadership of the parliamentary party belonged to the duchy's Establishment, and like their American counterparts a few years later, they were able to round up the support of powerful governments abroad: Frederick the Great of Prussia, George III of England, who was also Elector of Hanover, and Frederick V of Denmark, who was with the Hanoverian and Prussian rulers, a co-guarantor of the Württemberg constitution. Rioting and rebelliousness was not uncommon in eighteenthcentury Germany, but hardly ever achieved substantial political goals. The urban variety usually involved journeymen protests as in Hamburg from the 1690s to 1712 , or among the shoemakers of Würzburg in 1726, among the Friedberg miners of 1728 , or as in the case of the protests of factory workers and journeymen in Hamburg in 1753 or the silk workers of Berlin in $1775 . .^{5}$ The Württemberg protests did not share these characteristics, nor did they mimic the many rural riots and demonstrations by peasants in favor of reducing labor services. The peasants often assembled in larger groups, carried sticks and tools as weapons, refused to pay their rents or do their weekwork. There were, for example, two major rebellions in Bohemia in 1755 and 1775 which were put down by armed force. Over 40,000 troops were used in suppressing each of these. ${ }^{6}$ The Württemberg rebellion of 1764 involved elements which were characteristic of the typical peasant protests of medieval and early modern times. Labor services (Frohndienste) were considered to be oppressive, and even when requisitioned by the army during wartime and slowly reimbursed, the work was considered an unnecessary burden. However the 1764 conflict was in actuality the result of cumulative grievances which were aggravated by the sudden imposition of a new and heavy tax on property and income affecting all segments of a society already burdened by a considerable war debt. Few cases of conflict may be as thoroughly studied as this one. The documentation on the so-called Landschaftsstreit runs to over 10,000 pages. The actual statistical data is much less extensive and has not been related to the socio-economic crisis which provided the context for the events which followed. The Württemberg conflict was an acute one, both on the level of local politics and for the realignments taking place in the north European balance of power after the Seven Years' War. ${ }^{7}$

The protests of the Württemberg parliament had been curbed during the war years because the situation demanded Württemberg's loyalty to the imperial cause. Frederick the Great had been declared an outlaw of the empire by the Reichstag; and for the states of the Holy Roman Empire that meant obedience to the Emperor Francis I and his direction of 
the war effort. ${ }^{8}$ Both German guarantors of the constitution, Hanover and Prussia, had been at war with the emperor. During the war, the Vienna court had encouraged Duke Charles Eugene to build up his armed forces and to bring the pro-Prussian sympathies of his parliament under control. To that end, Count Samuel von Montmartin, a Protestant supporter of the Habsburgs, had been recommended to the duke and had become Württemberg's first minister. ${ }^{9}$ By 1762 , however, the duke resolved to increase his military establishment, which was then already running at a deficit, to 10,000 men. This would require a tax revenue of 1.6 million gulden per annum which was to be collected in monthly installments from May to October, 1763, over the protests of the parliament (Landschaft) ${ }^{10}$. In spite of the war's ending in Germany with the Peace of Hubertusburg, signed on February 15, 1763, Charles Eugene accelerated his military build-up. Perhaps something in his personality compelled him to rival the palace building and military prowess of the Prussians, although his miserable military performance during the war had already made it plain that he lacked his father's military ability. His marriage to a niece of Frederick the Great in turmoil at the time, he seemed not sufficiently cognizant of the shifts taking place in the German balance of power to expect any change in Vienna's attitude towards him. But the peace treaty had obliged the King of Prussia to support the candidacy of Joseph, son of Maria Theresa and the Emperor Francis I, for selection as the emperor's designated successor, King of the Romans. To achieve this end the Habsburgs were more than eager to resolve internal differences in Germany and to return to a balance of power among the nine electors. Both of the two Protestant ones, Frederick II and George III were, however, also guarantors of the Württemberg contitution and used the opportunity of the election to persuade the emperor to send an emissary to resolve the differences between duke and parliament in Stuttgart. In spite of these negotiations during March and April of 1764, Charles Eugene went one step further and unilaterally decreed a new head and property tax (Kopf-und-Vermögens Steuer) on March 6, $1764 . .^{11}$

With the war over, the emperor was anxious to remain on good terms with Hanover and Brandenburg-Prussia and proved open to the arguments brought against the duke when the leaders of the parliament brought a legal suit against him before the Aulic Council (Reich Supreme Court) during the summer of 1764 . By that time military force had been used against the country, and the duke was actually at war with his own people. The rebellion of the spring and summer of 1764 was actually a tax strike, a refusal to accept the new tax. It involved a massive and 
thorough-going resistance in most of the ninety-three towns and counties of Württemberg. ${ }^{12}$

How deeply in debt the duchy was when the new tax was announced may be seen from the calculation of the Württemberg War Department's (Kriegs Kasse) debt presented to the Aulic Council by the parliament in 1765. For the year beginning May 1, 1763 and ending April 30, 1764, the cost of supplying seventeen regiments and batallions with bread, meat, food and wages cost 177,495 fl. $50 \mathrm{kr}$. and 3 Heller. ${ }^{13}$ However the total indebtedness of the War Department's Paymaster (Kriegs-Kasse) for the fiscal year 1763-64 was higher, and included such items as purchase of houses, building a church for Calvinist soldiers (though the duke was Catholic and the inhabitants Lutheran), and payment of recruiting bonuses. The general staff salary budget was low, $478 \mathrm{fl} .41 \mathrm{kr}$. and 1 Heller. It included the salaries of the war ministry personnel (Kriegs Rat) of $256 \mathrm{fl} .22 \mathrm{kr}$. 4 Heller. Also salaries owed prisoners of war captured in 1760: $3351 \mathrm{fl}$. 39kr., with payment to dependent wives amd children of 10,115 fl. $42 \mathrm{kr}$. Monies obtained from the Church Treasury (Kirchen Kasten) were to be repaid amounting to $104,296 \mathrm{fl}$. $32 \mathrm{kr}$. $5 \mathrm{H}$. while $11,6145 \mathrm{fl}$. $51 \mathrm{kr}$. was to be repaid to the parliament. Hospital costs were only $204 \mathrm{fl}$. $30 \mathrm{kr}$. but flags and standards cost $2080 \mathrm{fl}$. $12 \mathrm{kr}$. while purchase of rifles amounted to $6076 \mathrm{fl}$. $41 \mathrm{kr}$. Since the towns and counties were required to pay for troops quartered upon them, another 50,234 fl. $37 \mathrm{kr}$. and $3 \mathrm{H}$. could be raised. Still greater was the item for gunpowder and saltpeter from the Saltpeter Administration in Stuttgart: 63,401 fl. 41 $\mathrm{kr} .5 \mathrm{H}$. Another large item was for support of invalids and pensioners up to April, 1765. The spread sheet presented to the Aulic Council in May, 1765 listed the Kriegsrat obligation to pay 300,000 fl. in salaries and pensions for 1764-65. Even though many officers and men had been mustered out, half $(150,000 \mathrm{fl}$.) of this sum could not be met, nor could the interest on its capital be paid. The total debt of the War Department Paymaster (Kriegs Kasse) was thus 1,393,818 fl. $1 \mathrm{kr} .2 \mathrm{H}$. according to the figures presented by the Landschaft's commissioner to the Aulic Council on Aug. 31, 1765. ${ }^{14}$

How serious the government's financial crisis was by the end of 1763 may be seen from the data presented in the Paymaster's accounts. If one deducts the $300,000 \mathrm{fl}$. owed on salaries and pensions, it becomes apparent that by the spring of 1764 the liabilities of the War Department were already about one million gulden, and in excess of the revenues raised by the monthly military taxes collected by the duke during that year. This had brought in only $810,934 \mathrm{fl} .6 \mathrm{kr}$. and left a deficit of about $200,000 \mathrm{fl}$. which could not be met out of the regular annual appropriation of the parliament. The annual sum approved by the Landschaft 
amounted to only $460,000 \mathrm{fl}$. and could not be used to finance the deficit on the military accounts since it was also intended to fund the debt repayment schedule on long term accounts. Further, because of the duke's unwillingness to negotiate with the Landtag (diet) summoned in the fall of 1763 , the parliament had refused to appropriate the full sum and only $230,000 \mathrm{fl}$. had been collected during the winter of 1763-64. ${ }^{15}$

To deal with the immediate crisis, Charles Eugene and Count von Montmartin decided to by-pass the parliament and the annual appropriation by imposing a new tax on the towns and counties which could be enforced by military absolutism. The duke urged his county administrators (Oberamtmänner) to refer to the new Head and Property Tax as an equalizing measure which would tax the wealthy as well as the usual rural taxpayers and the poor who had borne the brunt of the tax burden in the past. In actual effect, the assessment of inventories, mercantile goods bought on credit and not even paid for, as well on personal goods and farm properties was so high that many taxpayers found themselves in a much higher tax bracket than before. But the taxpayers had not consented to the tax, Montmartin had drawn it up without consulting the parliament. ${ }^{16}$ The right to approve taxes had been granted to the parliament in the Tübingen Compact of 1514 and repeatedly confirmed by successive dukes upon their accession. The emperors, the Reichstag, and the guarantor powers had also guaranteed the constitutional compacts. The duke and Montmartin had however planned to circumvent the regular system and issued the new tax patent in secret on March 6, 1764. Charles Eugene had gone in person to instruct his county administrators, the Vögte or Oberamtmänner, at the end of March, and gave specific instructions on what the local assemblies were to be told about the tax. The regular meetings of the county assemblies, Amtsversammlungen, were attended by the Vogt, the magistrate and burgomasters of the county seat and by some of the sheriffs (Schultheissen) and burgomasters of the county's villages. Although they had no constitutional right to consent to the duchy's taxes, the duke now intended to use them for that purpose. All Amtsversammlungen were to be held simultaneously, on a few hours notice, in every county on March 31,1764 . The arguments to be presented by the Vogt, who was not to leave the room (as the law required) after he had read the ducal proposals, were set out for him. Those who resisted were to be warned and if they persisted, to be arrested and sent to Stuttgart. The assent was to be 'voluntary,' yet under threat of arrest if refused, and for the Vogt, under threat of dismissal if he failed to secure the consent of the Amtsversammlung (County Council). ${ }^{17}$ 
The records of ten of the county meetings survived and were collected by the privy council. They represent the types of opposition encountered if not the genuine feeling of the villagers, townsmen, mayors, and taxpayers in the over ninety counties of the duchy. Among the ten opposing counties, many were agreeable to the tax only on condition that the Landtag be called at an early date and a return to the traditional procedures instituted. Several of the magistrates took the opportunity to renew their complaints against excessive labor services and the hardship of the tax. Often the exhaustion of cash funds and the previous heavy tax rate were cited as causes of their inability to pay. Most of the officials expressed their loyalty to the duke and seemed to fear punishment for lèse majesté. Just as in the American Revolution a scant decade later, the quartering of troops was a frequent cause of complaint. A few stalwarts held out against the duke's psychology of intimidation and threat of arrest: the ninety-year old major of Schorndorff, Weitbrecht, resisted only mildly. He realized the times were hard. Hailstorms and weather damage had ruined the crops and many of the subjects were too poor to pay even the ordinary taxes.

In Urach, the centre of a once prosperous linen-weaving industry, Oberamtmann Georgii, who had succeeded his father in the office forty years earlier, made a highly personal appeal to his many friends on the county council. The deputies on it had concluded that a protest would not do much good anyway and agreed to a one year trial for the tax. In Tübingen, seat of the university and of the duchy's appeals court, opposition had not yet jelled: Huber, the presiding official, urged acceptance of the tax patent on March 31. By June he was to be arrested for opposing it. The parliamentary party recognized the danger more quickly. Tübingen's Mayor Dann was also a member of the Small Committee, the parliament's steering committee, and with 49 deputies of the Tübingen county council, protested at once. Dann called for a return to the proper procedures: the duke ought to negotiate with the parliament. As a member of the parliamentary executive he felt that duty impelled him to refuse the illegal tax. The second mayor, Kohler, thought the tax project impossible; the third, Georgii, could not understand the patent on first reading. The majority then advocated a new negotiation between duke and parliament, and wanted to be spared the tax. In Nürtingen, which was closer to Stuttgart, twenty out of thirty deputies of the county council refused the tax. The opposition was arrested and sent to Stuttgart where most of them were forced to sign a consent document on April 5, $1764^{18}$.

The Nürtingen opposition was led by Jakob Friedrich Duttenhofer (1697-1769) who had been director of the Spital, or local charitable trust 
and hospital whose incomes went to support the poor. Large sums of the capital of the trust had been loaned to the duke during the war. Duttenhofer was also a member of the parliament, and played a role in negotiating the Settlement or Erbvergleich of 1770, which eventually restored the constitution and arranged for funding the debts incurred during and after the Seven Years' War. Conciliatory by nature, Duttenhofer agreed that the new tax had some merit, but that approval of taxes was the concern of the parliament (Landtag). For his part, he could not consent to such an injury of his country's freedoms. The Vogt Faber, a man who had organized spinning instruction in the county poorhouse, was enraged at the opposition. Since March 31 fell on a Saturday, the twenty opponents decided to go to Stuttgart only on Monday to face the charges levied against them. Duttenhofer delayed an additional day since he was ill, and by evening the duke's regiment of horse guards arrived and demanded immediate quarters for his troops. The regiment arrived Tuesday morning with 180 men and officers, 79 women and 89 children. Most of the officers were billeted with the town's officials. When the recalcitrant magistrates appeared before Duke Charles Eugene on April 5 , only Duttenhofer still held out. The duke was curt, and wanted only a yes or no answer about signing the tax agreement. When he refused he was ordered to leave town. The other deputies signed under pressure. Duttenhofer was to be punished by having sixteen soldiers quartered in his household and by being placed under house arrest; he was denied permission to write letters. Soon, the terms of his punishment were modified and he wound up with only three soldiers in his house. By April 13, however, more troops poured into the rural districts of Nürtingen county. But those who had signed in Stuttgart had their fines reduced from $100 \mathrm{fl}$. to $14 \mathrm{fl}$. Duttenhofer seldom attended meetings of the county council after this incident, but remained active in the parliament for several years to come. ${ }^{19}$

Meanwhile the more massive opposition began to develop in the countryside during the first few weeks of April when the new tax forms were distributed, and then widely refused. At the same time Joseph II had just been crowned King of the Romans and Francis I's successor as emperor in Frankfurt Main. His election had been secured against at least one promise that the imperial government send an ambassador to Stuttgart to mediate the worsening conflict. The emperor's ambassador to the Frankish Circle, Baron Johann Wenzel von Widmann who was to be dispatched to Stuttgart, had to go to Swabian Circle assembly meeting in Ulm, and could not really go to Wüttemberg until June. However from his correspondence with the duke's prime minister, Baron von Montmartin, he was informed that the opposition stemmed mostly from the 
church leaders, an obviously wrong conclusion. Later he was to boast that he had sought the approval of the county councils, a move which showed that he wanted public support. On April 24 he had even informed the estates Great Committee that he would be willing to modify the tax once it was in effect. He refused to recognize the parliament's right to approve all financial measures relative to military affairs. A prejudice of this type ought not to stand in the way of creating a standing army. The duchy had long needed one. The towns and counties had accepted the new tax and since these elected the two estates committees, they had not the right to contradict what their own electors had done. He claimed that the accusation levied at him, that the approvals had been obtained by force and intimidation was not true. ${ }^{20}$ Charles Eugene appears to have been out of touch with the country. By April 5 a massive strike of the taxpayers had begun in Sindelfingen county where 500 citizens, led by county clergy and school officials refused to fill out the tax forms. Only then did the seventeen members of the magistrate petition for a return to the old system. ${ }^{21}$ By April 12, the Urach magistrate also wanted to reverse its earlier position; by the twenty-second, Sulz, centre of the cotton industry, had reconsidered. The magistrate and village officials refused the tax forms and then also refused to pay within eight days as commanded. Nor did they report to the county Vogt for punishment. They had widespread public support. Despite all threats the tax forms had been refused in the Sulz county seat and villages. ${ }^{22}$

The unrest spread. Tax protests began in Waiblingen on May 19; by June 15 the county was fined $1008 \mathrm{fl}$., the town notary $150 \mathrm{fl}$., and the communes over $85 \mathrm{fl} .{ }^{23}$ Violence began in Pfüllingen when 40 soldiers and eight grenadiers and four officers marched into the town. Two rebel leaders, a nailsmith and a barber-surgeon, were arrested, taken under military escort to Hohen Nueffen but released a few days later. Troops were also used in Balingen where four were arrested on May 29. Between May 2 and June 8 the Herrenberg magistrate held up return of the forms although an almost total boycott of the fourteen villages of the county led the duke to send in husars on May 25. The Herrenberg magistrate could not even pay the fines until they borrowed the money and sent it, finally, to the duke's tax collector, Councillor Gegel. Gegel, the author of an illuminating autobiography actually refused to accept the money and sent it to the privy council treasurer (Kammerrat Dillenius). ${ }^{24}$ The total boycotts in Leonberg county were even more provocative: the fines amounted to $3000 \mathrm{fl} .{ }^{25}$ In the largest city, Stuttgart, the merchant community objected most strenuously. The tax fell on their unsold inventories bought on credit and making up most of their real property. No deductions were allowed for costs and liabilities. The Stuttgart 
magistrate thought it more feasible to tax tax-free capital such as debentures issued by the consistory. The city had more debts than it could pay. The quartering costs had been high. The maintenance costs alone ran to $68,125 \mathrm{fl} .{ }^{26}$

The Tübingen incident proved to be the worst. Although the duke had already agreed to convene the Small Committee on May 29, he continued to try to collect the new tax in monthly installments. This led to monthly refusals and further incidents. Two cavalry regiments under General von Schönfeld had been dispatched on Monday, June 18. They demanded payment of the May tax arrears ( $3570 \mathrm{fl}$.) within 48 hours or two further infantry regiments would be quartered on the town. The county council met June 19 in the townhall, attended by General von Schönfeld and Colonel Thumb. The general read the proposition and supervised the voting. The county Vogt, Huber, then led the new resistance and refused to agree to the procedures or the tax. Two infantry regiments came in on June 22, while the townspeople looked on. Huber was arrested, Judge Steeb, deputy Lentz, the surgeon Raspe as well, and all were taken under military escort to Fort Asperg. Heavy quarterings were imposed on the townsmen. ${ }^{27}$

The parliament's Great Committe protested these events to the duke on June 21 and 22 and also to Baron von Widmann who had meanwhile arrived to investigate the conflict. Their petition, they hoped, would make it clear to the duke how desperate the situation in his country was, viz., the 'unbeschreiblichen Nothstand des landes sich zu Herzen dringen lassen.' They foresaw dire consequences for the entire country. Tübingen, already heavily in debt, had been asked to meet a tax bill of 76,666 $\mathrm{fl}$. a sum far in excess of the annual tax revenue of many of the towns and counties. The Great Committee pleaded for the release of the prisoners and the return to the old tax. On June 23 they described the emergency to Baron Widmann beseeching him to help to save Tübingen from total ruin. The country's constitution had been confirmed by the emperor and ought to be restored. He had to use his persuasive powers with the duke in order to save 'viel tausend arme Unterthanen von ihrem gäntzlichen Umsturz.'28

The parliamentary leaders had not been idle. The duke's two younger brothers were being considered as possible replacements for him; Frederick, the youngest was married to Frederick the Great's niece and had already arrived. Montmartin, the prime minister, told Widmann he too no longer knew what to do. The duke seemed to disregard the whole situation and devoted himself to a life of frivolous entertainments. No one was being paid. Hostile pamphlets had appeared in Stuttgart. Yet Montmartin seems to have avoided an attack on the duke. He claimed 
that the troops were only used to collect the arrears taxes. Widmann advised against such actions, making it clear that the emperor would not look favorably upon them. On June 23 he reported to Vienna that the impending rebellion (Garhrung) was serious enough to prevent him from leaving town just then. ${ }^{29}$ June 24 he found out about the Tübingen incident and demanded the release of the prisoners taken. Montmartin tried to justify the action as necessitated by the 'cause' of all sovereigns. The duke was merely trying to collect what was his. Then he broke down and complained that it was impossible to deal with the duke: he would not even listen to reports nor would he give in to his estates. Actually he wanted them to bring a case to the Aulic Council and that he would use the arrestees as hostages until the estates approved the sums he demanded. The estates was willing to appropriate the usual summer levy of $25,555 \mathrm{fl}$. per month. This was far below the sum needed to meet the immediate deficit of $200,000 \mathrm{fl}$. Montmartin agreed that the army had to be reduced to 6000 men down from 15,000 , but the duke seems not to have had a clear grasp of the situation. Twenty-one counties were in an emergency condition and poverty faced the nation. Yet the Tübingen troops were recalled by the 25th of June after the estates offered an $80,000 \mathrm{fl}$. advance. The events of June 22 and 23 had speeded up the intervention of the guarantor powers. On July 3 and after, emissaries arrived from Berlin, Copenhagen and Hanover to support the parliamentary party against both duke and emperor. ${ }^{30}$

Although the duke continued to send troops to collect the new tax, forces had now been set in motion which would compel him to convene a new parliament in October. A strong argument in favor of the intervention of the guarantors and of the imperial court in Vienna was the evidence of economic ruin which the estates were able to produce. That this affected Habsburg interests is certain: the House of Austria held an ultimate succession right to the duchy in case the Württemberg line died out. How heavy the debt load was in 1763-64 may be seen from the tables of indebtedness appended to this paper. The very good census returns collected in the duchy in the eighteenth century made possible a per capita calculation not of the actual debt load, but of the estimated load. The actual indebtedness could not be known and was higher than indicated. The worst and most pressing burdens were described in the parliament's records which remain incomplete. (See Table.)

The formula for determining welfare payments to the duchy's poor had been drawn up by Vogt Faber of Nürtingen and set the minimum subsistence level at between 30 to 35 gulden a year. Incomes below that were eligible for supplemental allowances graded so that the sum allotted depended on how much was needed to reach the minimum subsistence 
level. The March 6, 1764 tax levied taxes on even the welfare recipients' income. More than that, the value of the property assessed was revised so that the taxpayer found himself in much higher tax brackets than before. ${ }^{31}$ Under the old system the actual citizens of the towns and the higher income farmers and craftsmen had paid the taxes. Yet only about $20 \%$ of the inhabitants were actual citizens even though the new tax also taxed the poor who were not. The debt load reported when the new tax was imposed fell on the former class of taxpayers and more heavily than indicated since the description only shows the average distribution based on total resident population and including women and children (who also often worked). About two thirds of the population earned less than 60 to 75 gulden a year. That quartering costs had to be paid, as well as the transport and hauling services, repairs, road tolls, and a host of excise and indirect taxes must be kept in mind too. The average debt load of $5 \mathrm{fl}$. or $8 \mathrm{fl}$. a year would fall heavily on the welfare recipients who earned 30 or $40 \mathrm{fl}$. a year. Some exceptional poverty existed. Herrenberg's average debt load was $87.5 \mathrm{fl}$. a year for the 2000 tax paying families who had paid $175,000 \mathrm{fl}$. in war taxes since 1757 , but only 14.58 $\mathrm{fl}$. a year to $22 \mathrm{fl}$. for the payment of sales taxes, duties, and tithes. Neuenburg's debt of $171,097 \mathrm{fl}$. had to be borne by 1200 citizens, a burden of $142.58 \mathrm{fl}$. per capita. Urach's debt of $622,307 \mathrm{fl}$. averaged 27.52 fl. per capita. ${ }^{32}$ The existing misery and prospect of future unrest threatened the peace of the empire which had been only recently restored. No one wanted another war. The Habsburgs had based their claims to the imperial office on their ability to uphold a fair and impartial justice in all disputes within the empire and this principle was not put to the test.

On July 30, 1764, Frederick the Great wrote to Francis I, 'Kaiserliche Majestät,' requesting him to uphold the Wüttemberg compacts and alleging that he had already written to Charles Eugene as a friend. Frederick wanted the emperor to curb the influence of evil advisers (Montmartin) and to end the illegal projects which were ruining the country. The emperor was to protect the parliament and maintain the duchy's freedom. ${ }^{33}$ Francis I replied to the King of Prussia on August 15 that it was his duty as emperor to provide peace and order, to protect the rights and privileges of all subjects. He realized that it was his duty as head of the empire to maintain the constitution of each land and so the case was to be turned over to the Reich's Supreme Court (Reichshofrat) or Aulic Council. It would begin a legal investigation and render an objective verdict. ${ }^{34}$ George III hastily backed up Frederick's plea with his own letter to Francis I, dated August 21, 1764, in which he referred to the 'ganz unerhörte Steueren' and condemned the harsh military excesses and ex- 
cessive and unilaterally imposed taxes..$^{35}$ George III had specifically requested the emperor's intervention as the highest judge of the Reich (Obristrichter) and asked for the protection of the Wüttemberg parliament as well as an order to inhibit the duke's actions. The original pristine legal state was to be restored by a strict adherence to the Reich's laws. ${ }^{36}$ The Danish royal letter of Frederick V of September 14, 1764 backed up the demands of the two earlier ones. ${ }^{37}$ Consequently the emperor acted through the Aulic Council which reached its decision August 28, 1764 and on September 6, 1764 issued its decree. The emperor had heard the complaints and ordered the duke to call a new session of parliament and to do so according to customary procedures. He was also enjoined to release the parliament's legal consultant, Johann Jakob Moser, who had languished in prison without writing tools for five years because of his protests against the duke's violations of the constitution during the war. Charles Eugene was especially admonished not to try to hinder the parliament in its future recourse to the imperial court. If the duke resisted further and again refused to return to the constitutional procedures, he would be held in contempt of the Aulic Council and the emperor. ${ }^{38}$ In spite of this admonition he actually continued to demand the monthly tax until October. Many towns and counties were two or three months in arrears by then because they had refused to pay it in the summer. Calw complained on Sept. 11 that troops had been quartered in the town since June 26 and that the military commander wanted them to pay the four months back taxes or he would call in reinforcements. A meeting of citizens with representatives of the guilds in this heavily industrial town resulted in a unanimous rejection of the new tax demand and a firm adherence to the argument that the tax was unconstitutional and illegal. More troops were sent in and 138 soldiers and 30 wives quartered at the expense of the town's officials and also in the households of the office staff and directors of the Calw Woolen Manufacturing Company. This hindered the work of the company whose officials had been away at the fall fair in Frankfurt. Their wives had been exposed to the advances of the rough soldiery. In Nürtingen there were further incidents too. On September 6 General Major von Holle demanded the August payment of $1806 \mathrm{fl}$. and threatened new grenadier detachments and quarterings if refused. The magistrate asked the village sheriffs (Schultheissen) to consult with their taxpayers and also handed the General Major the excerpt of the Aulic Council's minutes of July 30 and August 3 . The General replied by saying he did not read Latin and that he took his orders from the duke. He did not need new orders. Fresh troops came on the evening of Sept. 7. In spite of it, the magistrate resisted. They feared the disapproval of the emperor more. They hoped 
the officer would seek new orders from the duke. The Aulic Council had recently acted on the case. ${ }^{39}$

Further military executions had taken place between August 6 and October 23 in Wildberg, Heidenheim, Schorndorff, and Leonberg. The last attempts to collect the illegal tax had failed by the end of September even though the duke still ignored the imperial order to stop collecting the tax and still tried to intimidate the county of Sindelfingen with force. Since the magistrates could reply with the support of the emperor's authority, Charles Eugene began a new negotiation with his parliament on October $25,1764 .{ }^{40}$

After nearly five years of negotiations between lord and land backed by the active mediation of the Prussian, Hanoverian and Danish ambassadors, a Settlement (Erbvergleich) was signed in 1770. The duke gained virtually nothing. The total debt was estimated at 4 million gulden assessed as liabilities of the ducal domains treasury and the war department (Kriegskasse). A special fund was to be set up to pay it off. Some 190,000 fl. per annum was to come from the ducal revenues from excises and tariffs ( $Z$ oll) as well as from the sales tax (Umgeld). Included was the revenue from the salt factory in Sulz, the two state owned iron works and the three wood processing plants. To it, the parliament would add $90,000 \mathrm{fl}$. a year so that a grand total of $280,000 \mathrm{fl}$. would be available to pay off the debts and make restitution for damages caused by excessive labor services and quarterings. The old funding scheme devised in 1739 still tied up 70,000 fl. each year which was eventually to be added to the new funding revenues once the old debt was paid. Then $350,000 \mathrm{fl}$. per annum would become available. The annual budgets would remain close to what they had been before the Seven Years' War in spite of rising prices and changing needs. A sum of 20,000 fl. for the Circle military and ducal forces was to be added to the budget. The sum appears to have been deducted from the debt repayment schedule for the 1739 funding scheme. However the total of $360,000 \mathrm{fl}$. per annum raised by the ordinary taxes were to remain at that level, supplemented only by a $100000 \mathrm{fl}$. Tricesimarum tax. Thus $460,000 \mathrm{fl}$. was available annually to repay the ducal debts and to support the defense forces. This was exactly the same as the pre-war and official wartime sums! In case of future war some of the money used to repay the ducal debts could be discontinued and added to the military appropriation needed for the duke's and the Swabian Circle forces. Further sums could be raised only if the parliament were consulted. Here a special approval could divert funds from the church's revenues, but only after approval had been given. As a special settlement, however, the parliament did agree to a gift of 15,000 
fl. a year for four years as a token of appreciation, actually as a present for the conclusion of the Settlement. ${ }^{41}$

For the time being the absolutist tendencies had been met by the balance of power within the empire. The emperor had maintained the laws, compacts and traditions according to the requirements of his office in spite of principles of raison d'etat and without resort to conflicts grounded in religious antagonisms. The attempt made by Charles Eugene to suppress the Württemberg estates had been prevented by a combination of forces: the intervention of Frederick of Prussia, the leading enlightened despot in the empire, supported by the King of England, and the same one, George III, who would be confronted by the rebellion of his colonial estates a decade later. Joseph II, Emperor from 1765, attempted to reduce the role of religious hostilities in the politics of the empire and brought the long negotiation to a close, partly because he was willing to cooperate with the Prussians in an eastward expansion, the partition of Poland, and wished to gain Frederick's cooperation. Thus the combination of enlightened absolutist monarchy and the respect of the monarchs for the rights and privileges which they had sworn to protect, held a more active priority over the absolutism of the age which in the hands of Charles Eugene had tended towards the suppression of the estates and the disregard of monarchical agreements. The strongest impelling force acting in this situation was less the mysterious 'Zeitgeist' of Enlightened Absolutism, than the urgency of the economic crisis evoked by the actual policies which the stronghanded ruler sought to impose. The point of the greatest financial pressure produced sufficient opposition to mobilize the efforts of those who could most efficiently bargain for an agreement to secure the restoration of the existing legal order.

Some other factors which were involved might deserve mention. Württemberg was responsible for the Swabian Circle defense forces to a large extent. The frequent wars in the southwest during the reign of Louis XIV had made stronger troop contingents necessary. Yet fiscal urgency made this less than feasible in peacetime. Like the Swiss, the Württembergers preferred neutrality, a neutrality which they could not always have. That their economy was less than able to build a stronger defense force while at the same time maintaining the rights of the parliament left the old Holy Roman Empire weak in the strategic southwestern corner and probably contributed to its complete collapse in the Napoleonic Era. The parliamentary traditions survived and developed during the next two centuries. Württemberg's parliament was the subject of Hegelian political philosophy. Had the absolutism of the duke succeeded, and even if the parliament had been suppressed (as it was briefly during the Napoleonic era), the strong reluctance of the inhabitants to 
support military enterprises or follow less than competent military commanders would not have improved the survival chances of the ancien regime in the German southwest. The strong and cohesive local spirit and the enormous tenacity which the Württembergers showed, from 1457 into the twentieth century, did contribute to the survival of the constitutional state which they had built in the early modern era. Their success in the 1764-70 conflict, which could have turned into a decisive victory for the absolutist party in the empire, instead provided the turning point towards modern parliamentary government. ${ }^{42}$

\section{HELEN LIEBEL-WECKOWICZ \\ University of Alberta}

\section{NOTES}

1 Arthur Müller, Die Deutschen. Ihre Klassenkämpfe, Aufstände, Staatsstreiche und Revolutionen (Munich, 1972), 11-13 surveys the uprisings recorded for the years 1000 to 1234 .

2 Müller 16. On the Wat Tyler uprising see the summary in C.W. Previté-Orton, The Shorter Cambridge Medieval History. (Cambridge, 1952), II $987 \mathrm{ff}$. Theodor Schieder, ed., Handbuch der Europäischen Geschichte. (Stuttgart, 1971), III, 516-18, discusses the 1525 Peasants' War.

3 Walter Grube, Der Stuttgarter Landtag, 1457-1957 (Stuttgart, 1957), 83-6

4 Helen P. Liebel-Weckowicz, 'The Revolt of the Württemberg Estates, 1764-1770,' Man and Nature. Proceedings of the Canadian Society for Eighteenth-Century Studies (Montreal, 1984) 109-19

5 Müller, 75

6 Ibid., 74-5; on Bohemia see Helen Liebel-Weckowicz \& Franz J. Szabo, 'Modernization Forces in Maria Theresa's Peasant Policies, 1740-1780,' HistoireSociale/Social History 15 (1982) $316 \mathrm{ff}$.

7 Helen Liebel-Weckowicz, 'Count J.H.E. von Bernstorff's German Policy and the Balance of Power in Northern Europe, 1764-1772,' The Third Conference on Baltic Studies in Northern Scandinavia: I. History Section (Stockholm, 1977) $101-20$

8 Leo Just, ed., Deutsche Geschichte vom Zeitalter der Reformation bis zum Tode Friedrich des Grossen, in Handbuch der Deutschen Geschichte (Constanz, 1956), II, 62-86. Although Frederick the Great was declared an 'outlaw' of the empire by a majority vote of the Reichstag (Imperial Diet) on January 17, 1757, Charles Eugene's representative did not vote for the Reich action against him which was 
decided then, although he had begun a mobilization of his forces in early January. Karl Eugene und seine Zeit. (Stuttgart, 1904), vol. I/Heft 3-4, 209.

9 Gerhard Storz, Karl Eugen: Der Furst und das 'alte gute Recht' (Stuttgart, 1981), 87

10 Herman Weisert, Geschichte der Stadt Sindelfingen 1500-1807 (Sindelfingen, 1963), 265

11 Helen Liebel-Weckowicz, 'Revolt of the Wuerttemberg Estates,' 114-15; also idem, with Franz Szabo, 'Modernization Forces,' 301-33

12 Helen Liebel-Weckowicz, 'Revolt of the Wuerttemberg Estates,' 116

13 Hauptstaatsarchiv, Stuttgart. A 34, Bü 105, Lit. 00000

14 Ibid.

15 Ibid. A 34, Bü 105, Recapitulatio. Since the Landtag which had convened on September 19, 1763 had been dissolved on Oct. 29, 1763, the only business completed was the appropriation of the winter installment of the ordinary tax: the socalled Winter Anlage. Weisert, 267. For the speech from the throne (Proposition of the duke) see Sammlung der merkwürdigsten Staats-Schriften. Verhandlungen und Recesse, welche bey den würklich obwaltenden Strittigkeiten Sr. Herzogl. Durchlaucht des regierenden Herrn Herzogs zu Württemberg und Dero Landständen gewechselt worden. (Frankfurt \& Leipzig, 1766), I, 91-5.

16 J. Kocher, Geschichte der Stadt Nürtingen (Stuttgart 1924-28), I, 128

17 The secrecy which enshrouded the tax announcement violated existing constitutional procedures. See the reports to the Landschaft by the Rosenfeld magistrate, HStA, Stuttgart, A 34, Bü 105, Lit. SSSSS.

18 Ibid., A 8 III, Bü 56. Thesse are reports to the Privy Council (Geheim Rat) from the counties of Schorndorff, Urach, Tübingen, Nürtingen on the County Council (Amtsversammlung) meetings of March 31, 1764. They are signed by the ducal official (Oberamtmann or Vogt).

19 Kocher, I, 129-32

20 Otto Friedrich Winter, Repertorium der diplomatischen Vertreter aller Länder. (Graz-Cologne, 1965), III, 67

21 Weisert, 268

22 HStA, Stuttgart. A 34, Bü 105, Lit. SSSSS on the incidents in Urach of April 12, 1764, and of April 22 and May 14 in Sulz/Neckar.

23 Sammlung ...Staats-Schriften, I, 148

24 HStA, Stuttgart, A 34, Bü 105, Lit. SSSSS for the incidents in Pfüllingen on May 14, 1764, Balingen of May 29, Herrenberg of June 11, 1764.

25 Sammlung ...Staats-Schriften, I, 149

26 HStA, Stuttgart, A 34, Bü 105, Lit. SSSSS, May 3, 1764

27 Sammlung ...Staats-Schriften, I, 137-45

28 Ibid., I, 139-44

29 Haus-Hof-und Staatsarchiv, Vienna, V/I StK, Fasz. 144: Widmann Berichte 1764 
30 Ibid.

31 Helen P. Liebel, 'Der Beamte als Unternehmertyp in den Anfangsstadien der Industrialisierung: Johann Friedrich Müller und die Staats-und Wirtschafts-reformen Württembergs, 1750-1780,' Entstehung und Wandel der modernen Gesellschaft. Festschrift fur Hans Rosenberg zum 65. Geburtstag, ed. Gerhard A. Ritter (Berlin, 1970) 221-60

32 See Appendix Table I.

33 Sammlung ...Staats-Schriften, I, 155-60

34 ibid., 161-2

35 ibid., 163-4

36 Ibid., 166-7

37 Ibid., 168

38 Ibid., 171-4

39 Ibid., for Nürtingen, September 7, 1764; and HStA, Stuttgart, A 34, Bü 105, Lit. SSSSS, Calw, September 10, 1764

40 Ibid., also, Weisert, 270-1; Sammlung ...Staats-Schriften, I, 182-90 of October 29,1764 for the Speech from the throne (Ducal propopsition).

41 Abdruck des zwischen Seiner des Regierenden Herrn Hertzogs zu Würtemberg Hertzoglichen Durchlaucht. und gesamten Prälaten und Landschafft des Herzogthums sub dato 27. Februari und 2. Martii 1770. abgeschlossenen Erbvergleichs. Nebst beigefügter Kayserlicher Bestättigungs-Urkunde (Stuttgart, 1771), 109-12, 69-70, 55-57, 68

42 On the development of the Württemberg state see also the recent work James Allen Vann, The Making of a State: Württemberg, 1593-1793 (Ithaca and London, 1984), 256-300 
TABLE 1

\section{Debt Load of Selected Towns and Counties of Württemberg, 1756-63}

[Source: Streitschriften, II, 215-17. Population data from HStA, Stuttgart, A 8, III, 218. Data on Sindelfingen from Weisert, 264. On Neuenburg from HStA, Stuttgart, A 34, Bü 111 nro. 11. On Tuttlingen from A 34, Bü 105, Lit. OOOOO. On Leonberg, ibid., Lit. SSSSS Oct. 23, 1764]

\begin{tabular}{lccc}
$\begin{array}{l}\text { Towns and } \\
\text { Counties }\end{array}$ & $\begin{array}{c}\text { Debt Service } \mathcal{E} \\
\text { Loans }\end{array}$ & $\begin{array}{c}\text { Net } \\
\text { Population }\end{array}$ & $\begin{array}{c}\text { Incidence } \\
\text { per person }\end{array}$ \\
\hline
\end{tabular}

\begin{tabular}{|c|c|c|c|c|}
\hline \multirow[t]{3}{*}{$\begin{array}{l}\text { Stuttgart } \\
\text { (Town) }\end{array}$} & $\begin{array}{l}\text { debt service } \\
1758-63 \ldots\end{array}$ & . . 84,188 fl.13 kr. & \multirow{3}{*}{16,690} & \multirow{3}{*}{$7.18 \mathrm{fl}}$. \\
\hline & $\begin{array}{l}\text { monthly tax } \\
1763 \text { Jan. - Sept. }\end{array}$ & $\ldots 35,553 \mathrm{fl}$ & & \\
\hline & Total & $119,751 \mathrm{fl}$. & & \\
\hline $\begin{array}{l}\text { Stuttgart } \\
\text { (County) }\end{array}$ & & $38,277 \mathrm{fl} .20 \mathrm{kr}$ & 14,328 & $2.67 \mathrm{fl}$ \\
\hline \multirow[t]{2}{*}{ Tübingen } & \multicolumn{2}{|c|}{$\begin{array}{l}1763 \text { tax demands } \\
\& \text { military costs . . .96,993 fl. }\end{array}$} & \multirow{2}{*}{$\begin{array}{l}18,325 \\
\text { (sic) }\end{array}$} & $5.548 \mathrm{fl}$. \\
\hline & $\begin{array}{l}1763 \text { tax deman } \\
\text { damages ....... }\end{array}$ & . . $76,666 \mathrm{fl}$ & & $4.18 \mathrm{fl}$ \\
\hline Canstatt & $\begin{array}{l}\text { Tax arrears, sto } \\
\text { mages, quarterin }\end{array}$ & $\begin{array}{l}\text { age, fees, da- } \\
\text { g. } 93,353 \mathrm{fl} \text {. }\end{array}$ & 11,059 & $8.67 \mathrm{fl}$. \\
\hline $\begin{array}{l}\text { Lauffen } \\
\text { (3 villages) }\end{array}$ & $\begin{array}{l}\text { debt service } \& \\
\text { taxes } \ldots \ldots \ldots\end{array}$ & .. 49,045 fl. $20 \mathrm{kr}$. & 3,810 & $12.87 \mathrm{fl}$ \\
\hline Herrenberg & $\begin{array}{l}2000 \text { taxpeyers } \\
1757-64 \text { requisiti } \\
\text { taxes, excises ... }\end{array}$ & $\begin{array}{l}\text { ons \& } \\
.175,000 \mathrm{fl} \text {. }\end{array}$ & 7,948 & 14.58 fl. p.a. \\
\hline $\begin{array}{l}\text { Kirchheim } \\
\text { unter Teck }\end{array}$ & $\begin{array}{l}1761-62 \\
\text { requisitions }\end{array}$ & $.82,146 \mathrm{fl} .6 \mathrm{kr}$ & 14,482 & $5.67 \mathrm{fl}$ \\
\hline Urach & $\begin{array}{l}\text { requisitions } \\
1762-63 \ldots \ldots \\
1756-63 \text { total }\end{array}$ & $\begin{array}{l}. .80,398 \mathrm{fl} . \\
.145,773 \mathrm{fl} .\end{array}$ & 22,606 & $3.5 \mathrm{fl}$. \\
\hline Sindelfingen & debts 1763 & $.11,820 \mathrm{fl}$. & 2,053 & $5.75 \mathrm{fl}$. \\
\hline
\end{tabular}


TABLE 1 continued

\section{Debt Load of Selected Towns and Counties} of Württemberg, 1756-63

\begin{tabular}{|c|c|c|c|}
\hline $\begin{array}{l}\text { Towns and } \\
\text { Counties }\end{array}$ & $\begin{array}{c}\text { Debt Service } \mathcal{E} \\
\text { Loans }\end{array}$ & $\begin{array}{c}\text { Net } \\
\text { Population }\end{array}$ & $\begin{array}{l}\text { Incidence } \\
\text { per person }\end{array}$ \\
\hline Neuenburg & $\begin{array}{l}\text { debt } \ldots \ldots \ldots 171,097 \mathrm{fl} . \\
1764\end{array}$ & $\begin{array}{c}1,200 \\
\text { citizens } \\
6,636 \\
\text { inhabitants }\end{array}$ & $\begin{array}{l}142.58 \mathrm{fl} \text {. } \\
\text { /cit. } \\
25.78 \mathrm{fl} \text {. } \\
\text { each }\end{array}$ \\
\hline \multicolumn{4}{|c|}{$\begin{array}{l}\text { [The Kriegskasse, War Treasury, borrowed } \\
447,687 \mathrm{fl} .27 \mathrm{kr} .5 \mathrm{H} \text {. and paid no interest } \\
\text { before } 1764 \text { ] }\end{array}$} \\
\hline Leonberg & $\begin{array}{l}\text { Public \& Private } \\
\text { debts . . . . . . . 125,156 fl. }\end{array}$ & 9,510 & $13.16 \mathrm{fl}$. \\
\hline
\end{tabular}

TABLE 2

Public and Private Debts of Selected Towns and Counties of Württemberg in 1763

[Source: Streitschriften, I, 219-24, reports Oct. 10-11, 1763]

Towns and

Counties

$\operatorname{Debt}(s)$

Net Incidence Population per person

Bietigheim

Loans $.15,661 \mathrm{fl} .45 \mathrm{kr}$.

3,178

$4.93 \mathrm{fl}$.

Rosenfeld

public \& private debts . . . . . 127,640 fl. $\quad 5,681 \quad 22.97 \mathrm{fl}$.

Dornhan

private debts only .41,292 $\mathrm{fl}$.

$1,311 \quad 31.00 \mathrm{fl}$.

Urach

public \& private debts . . . . . . 622,307 fl. 22,606 $27,52 \mathrm{fl}$.

Altenstaig private debts only $.70,000 \mathrm{fl}$.

$5,329 \quad 13.14 \mathrm{fl}$.

